\title{
KARAKTERISASI FISIKOKIMIA BIOPLASTIK BERBAHAN DASAR KITOSAN TERTAUT SILANG ASAM SUKSINAT / PATI / POLY VINYL ALCOHOL
}

\author{
Retno Ariadi Lusiana ${ }^{1 *}$, Ahmad Suseno ${ }^{1}$, Abdul Haris ${ }^{1}$, Nabila Iftinan Sari ${ }^{1}$ \\ ${ }^{1}$ Departemen Kimia, Universitas Diponegoro \\ retno.lusiana@live.undip.ac.id
}

Artikel Info
Diterima
tanggal
02.09 .2021
Disetujui
publikasi
tanggal
20.10 .2021
Kata kunci :
chitosan,
succinic acid,
starch, PVA,
biodegradabili
ty, bioplastic

\section{ABSTRAK}

Bioplastik merupakan plastik yang dapat terdegradasi secara alamiah baik melalui serangan mikroorganisme maupun oleh cuaca. Lima series film tipis/bioplastik dibuat dari kitosan (CS). kitosan taut silang asam suksinat (CSSA), paduan CSSA dengan pati (CSSAP) dan paduan CSSAP-Poly Vinyl Alcohol (PVA) (CSSAPP). Penelitian dibagi dalam 3 tahapan utama yaitu penyiapan larutan CSSA, pembuatan bioplastik dan karakterisasi bioplastik meliputi uji: gugus fungsi (FTIR), berat dan ketebalan, kuat tarik, porositas, hidrofilisitas, pengembangan (swelling), ketahanan $\mathrm{pH}$, dan biodegradabilitas. Dari data yang dihasilkan didapatkan bahwa semua bioplastik yang dihasilkan memiliki kenampakan bening kekuningan, transparan, tembus cahaya, tidak kaku dan tidak mudah patah, hal ini menunjukkan bahwa bioplastik bersifat cukup kuat. Selanjutnya dari hasil spektra FTIR, terbukti bahwa reaksi taut silang CSSA, reaksi paduan dengan pati dan PVA berhasil dilakukan, dengan munculnya serapan di daerah spesifik seperti O-H, N-H, C-H, C$\mathrm{O}, \mathrm{N}-\mathrm{O}$, dan $\mathrm{C}=\mathrm{O}$. Penambahan pati dan PVA mempercepat proses biodegradasi dari 77 hari menjadi 10 hari. Kuat mekanik dan kelenturan bioplastik mengalami peningkatan.

\section{ABSTRACT}

Bioplastics are plastics that can be degraded naturally either through the attack of microorganisms or by the weather. Five series of thin films/bioplastics were made from chitosan (CS). succinic acid crosslinked chitosan (CSSA), CSSA alloy with starch (CSSAP) and CSSAPPoly Vinyl Alcohol (PVA) alloy (CSSAPP). The research was divided into 3 main stages, namely the preparation of CSSA solutions, the manufacture of bioplastics and the characterization of bioplastics including tests: functional group (FTIR), weight and thickness, tensile strength, porosity, hydrophilicity, swelling, $\mathrm{pH}$ resistance, and biodegradability. From the resulting data, it was found that all the thin films produced had a clear yellowish appearance, were transparent, translucent, not stiff and not easily broken, this indicates that the bioplastic is quite strong. Furthermore, from the results of the FTIR spectra, it was proven that the crosslinking reaction of CSSA, alloying reaction with starch and PVA was successfully carried out, with the appearance of absorption in specific regions such as $\mathrm{O}-\mathrm{H}, \mathrm{N}-\mathrm{H}, \mathrm{C}-\mathrm{H}, \mathrm{C}-\mathrm{O}, \mathrm{N}-\mathrm{O}$, and $\mathrm{C}=\mathrm{O}$. The addition of starch and PVA accelerated the biodegradation process from 77 days to 10 days. The mechanical strength and flexibility of bioplastics have increased. 


\section{PENDAHULUAN}

Plastik merupakan bahan kemas utama dalam dunia pengemasan karena fleksibel, transparan, lentur, tidak mudah pecah dan ringan, namun buangan plastik yang semakin meningkat menyebabkan masalah lingkungan. Plastik memiliki struktur molekul kompleks yang menyebabkan sulit diuraikan oleh mikroba, dan terakumulasi dan menimbulkan pencemaran dan kerusakan lingkungan. Berbagai upaya telah dilakukan untuk mengurangi pencemaran oleh plastik, seperti reuse dan pengolahan ulang buangan plastik, namun hal ini membutuhkan cost yang tidak sedikit. Salah satu upaya efektif untuk mengurangi sampah plastik adalah membuat plastik yang ramah lingkungan/bioplastik. Bioplastik adalah plastik yang dibuat dari polimer alam, seperti kitosan, pati, selulosa, alginate, poli laktat dan beberapa biopolimer lain yang mudah terurai oleh aktivitas mikroorganisme ketika dibuang ke lingkungan (Sinaga dkk., 2014).

Seiring dengan kebutuhan yang meningkat akan bioplastik, mensyaratkan ketersediaan bahan baku yang mudah, murah dan berlimpah. Bahan yang mulai dikembangkan sebagai bahan dasar bioplastik adalah kitosan. Kitosan cukup potensial karena struktur kimianya, biodegradabel, non-toksik, biokompatibel, kemudahan pembentukan menjadi bioplastik, mempunyai sifat antioksidan, antimikroba dan mempunyai gugus yang reaktif (Haghighi dkk., 2020). Kitosan sangat melimpah sehingga mudah diusahakan. Namun, dalam aplikasinya kitosan kurang kuat, mudah terpengaruh $\mathrm{pH}$ lingkungan, resistensi dan sifat penghalang terhadap uap air rendah sehingga sangat sulit untuk dibentuk menjadi plastik lembaran besar (Jabbar, 2017). Strategi untuk mengatasi kekurangan tersebut adalah melalui modifikasi baik melalui reaksi taut silang, pelapisan pada permukaan atau paduan dengan biopolimer lain (Haghighi dkk., 2020). Modifikasi tersebut dapat dilakukan dengan menambahkan agen taut silang dan menambahkan material untuk mempercepat waktu degradasi bioplastik. Selain itu, untuk meningkatkan kekuatan mekanik dan kelenturan bioplastik dilakukan penambahan zat aditif, berupa plasticizer (Aditya dkk.,2021).

Penelitian ini dilakukan pembuatan bioplastik berbahan dasar kitosan tertaut silang asam suksinat (CSSA). Taut silang dengan asam suksinat dimaksudkan untuk meningkatakn kekuatan mekanik dan keseragaman struktur kitosan. Untuk meningkatkan biodegradabilitas dilakukan pemaduan menggunakan pati tapioka dan untuk meningkatkan kelenturan bioplastik maka ditambahkan zat aditif berupa PVA sebagai plasticizer. 


\section{METODE}

\section{Sintesis Bioplastik Bioplastik}

Pembuatan bioplastik diawali dengan membuat larutan kitosan 1,5\%, larutan pati 1,5\%, larutan PVA 1,5\%, dan larutan kitosan taut silang asam suksinat. Proses taut silang berdasar metoda yang telah dikembangakan oleh Lusiana dan Protoningtyas, 2018, sebanyak 1,1071 g asam suksinat digunakan dalam proses taut silang. Asam suksinat dilarutkan dalam $10 \mathrm{~mL}$ $\mathrm{CH}_{3} \mathrm{COOH} 1 \%$. Setelah itu, diteteskan dalam larutan kitosan $\left(1,5 \mathrm{~g}\right.$ dalam $90 \mathrm{~mL} \mathrm{CH}_{3} \mathrm{COOH}$ $1 \%$ ) kemudian diaduk menggunakan magnetic stirrer dengan suhu $55^{\circ} \mathrm{C}$ selama 4 jam. Setelah itu, membuat larutan untuk komponen bioplastik bioplastik dengan komposisi seperti pada Tabel 1 dengan waktu sintesis untuk bioplastik paduan bioplastik adalah 45 menit dalam suhu $45^{\circ} \mathrm{C}$.

\section{Tabel 1. Komposisi Bioplastik Bioplastik}

\begin{tabular}{|c|c|c|c|c|c|}
\hline \multirow{2}{*}{$\begin{array}{l}\text { Kode } \\
\text { Bioplastik }\end{array}$} & \multicolumn{5}{|c|}{ Volume Larutan (mL) } \\
\hline & CS & Pati & CSSA 0,5 & CSSA 1 & PVA \\
\hline $\mathrm{CS}$ & 5 & & & & \\
\hline CSSA & & & & 5 & \\
\hline CSSAP & & 2,5 & & 2,5 & \\
\hline CSSAPP & & 2 & & 2 & 1 \\
\hline
\end{tabular}

Pembuatan bioplastik dilakukan dengan cara menuang larutan sebanyak $5 \mathrm{~mL}$ ke dalam petri dish, kemudian dikeringkan menggunakan oven. Setelah itu, menambahkan larutan $\mathrm{NaOH}$ kemudian dicuci menggunakan akuades sampai $\mathrm{pH}$ bioplastik netral lalu dikeringkan.

\section{Karakterisasi Fisikokimia membran CC}

\section{Karakterisasi FTIR}

Bioplastik hasil sintesis dikarakterisasi menggunakan spektrofotometer FTIR untuk mengidentifikasi gugus fungsi yang ada pada bioplastik. Instrumen FTIR yang digunakan yaitu Spektrum 100-Perkin Elmer. Sampel dibentuk menjadi pelet dan dimasukkan dalam tabelt holder yang telah dilapisi pelet $\mathrm{KBr}$ dan direkam dengan inframerah. 


\section{Berat dan Ketebalan}

Pengukuran berat bioplastik dilakukan menggunakan neraca analitik OHAUS dengan menimbang sampel sebanyak tiga kali pengulangan. Data dari berat bioplastik dihitung rataratanya sehingga diperoleh nilai berat bioplastik seperti pada persamaan berikut:

$$
\text { Berat }=\frac{\text { berat } 1+\text { berat } 2+\text { berat } 3}{3}
$$

Pengukuran ketebalan bioplastik dilakukan menggunakan thickness meter dengan tiga kali pengulangan pada tiga titik yang berbeda. Data dari ketebalan bioplastik dihitung rata-ratanya sebagai ketebalan akhir bioplastik seperti pada persamaan berikut:

$$
\text { Ketebalan }=\frac{\text { titik } 1+\text { titik } 2+\text { titik } 3}{3}
$$

\section{Kuat Tarik}

Bioplastik hasil sintesis dengan ukuran $25 \times 3 \mathrm{~cm}$ direndam dalam akuades hingga mengembang, lalu kuat tarik dan persen regangannya diukur menggunakan Tensile Strength Analyzer. Kuat tarik ditentukan dengan beban maksimum saat bioplastik ditarik dengan gaya tertentu hingga robek dan persen pemanjangannya didasarkan atas pemanjangan bioplastik saat putus.

\section{Porositas}

Sampel direndam dalam $10 \mathrm{~mL}$ akuades selama 24 jam, kemudian dikeringkan menggunakan tissue dan ditimbang sehingga didapatkan nilai $\mathrm{W}_{0}(\mathrm{~g})$ sebagai nilai berat basah bioplastik. Setelah itu bioplastik dikeringkan menggunakan oven dan ditimbang sehingga didapatkan nilai $\mathrm{W}_{1}(\mathrm{~g})$ sebagai berat kering bioplastik. Kemudian hasil porositas dihitung dengan menggunakan rumus pada persamaan berikut:

$$
P=\frac{W o-W 1}{V \cdot \rho w} \times 100 \%
$$

Keterangan:

$\mathrm{P}=$ porositas $(\%)$

$\mathrm{W}_{0}=$ berat basah bioplastik $(\mathrm{g})$

$\mathrm{W}_{1}=$ berat kering bioplastik $(\mathrm{g})$

$\mathrm{V}=$ volume bioplastik $\left(\mathrm{cm}^{3}\right)$

$\rho_{\mathrm{w}}=$ massa jenis air $\left(1 \mathrm{~g} / \mathrm{cm}^{3}\right)$ 


\section{Hidrofilisitas}

Bioplastik ditempatkan di atas wadah dengan latar belakang hitam lalu diberi 1 tetes akuades tepat di atas permukaan bioplastik yang diuji. Tetesan air pada permukaan diambil gambarnya dengan angle kamera sejajar dengan bioplastik. Untuk mengetahui besar sudut kontak $(\theta)$ air terhadap bioplastik, gambar tetesan air diproses menggunakan perhitungan sudut trigonometri.

\section{Pengembangan (Swelling)}

Sampel bioplastik dihitung berat kering kemudian bioplastik direndam dalam $10 \mathrm{~mL}$ akuades selama 24 jam. Setelah itu, bioplastik dihitung berat basah dan besar pengembangan dihitung menggunakan rumus pada persamaan berikut:

$$
S D=\frac{W 2-W 1}{W 1} \times 100 \%
$$

Keterangan:

$\mathrm{W}_{2}=$ berat basah bioplastik $\mathrm{g}$ )

$\mathrm{W}_{1}=$ berat kering bioplastik $(\mathrm{g})$

\section{Biodegradabilitas Bioplastik}

Uji biodegradabilitas dilakukan dengan memotong bioplastik menjadi ukuran $2 \times 1 \mathrm{~cm}$ menggunakan penggaris dan dihitung luasnya. Kemudian potongan bioplastik tersebut ditanam dalam tanah humus berkompos sampai terdegradasi seluruhnya.

\section{HASIL DAN PEMBAHASAN}

\section{A. Film Bioplastik}

Dapat dilihat bahwa wujud fisik film berwarna kekuningan dan bening, tidak kaku, tidak mudah patah ketika dilipat-lipat yang menunjukkan bahwa bioplastik tersebut bersifat cukup kuat.

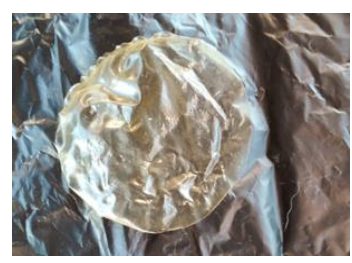

CS

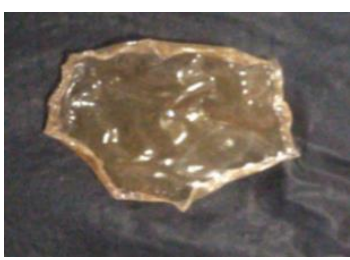

CSSA

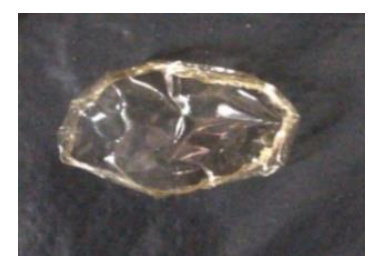

CSSAP

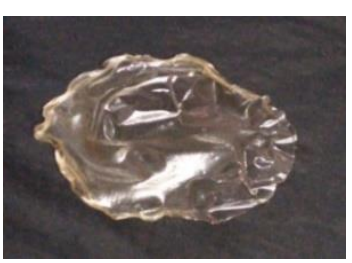

CSSAPP

Gambar 1. Film bioplastik 


\section{B. Karakterisasi Film}

\section{Gugus Fungsi (FTIR)}

Berikut merupakan spektra FTIR dari kitosan (CS), pati, PVA dan kitosan termodifikasi

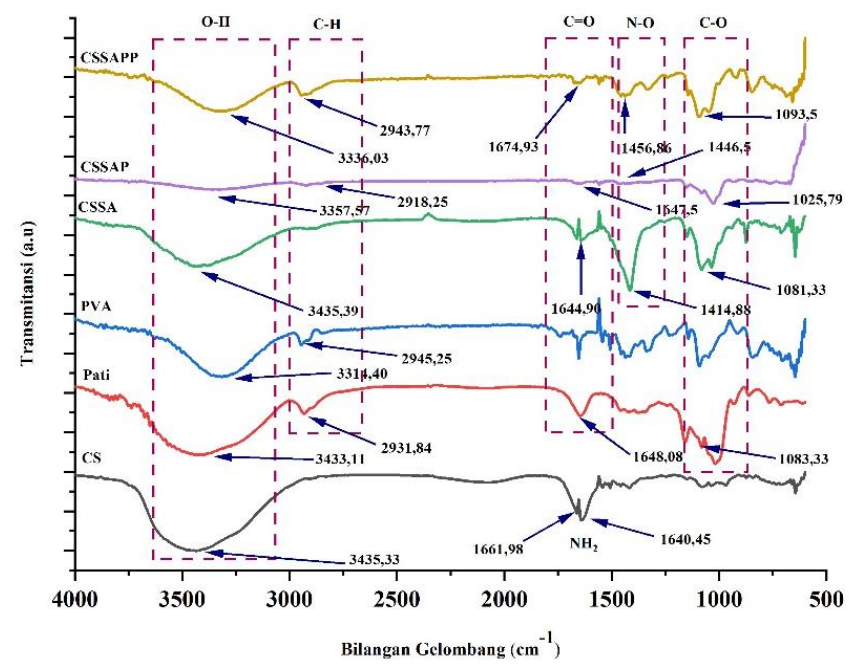

Gambar 2. Spektra FTIR dari film

Spektra spesifik kitosan ditunjukkan oleh serapan di daerah $3435,33 \mathrm{~cm}^{-1}$ yang merupakan serapan gugus $\mathrm{O}-\mathrm{H}$ dan $\mathrm{N}-\mathrm{H}$ yang bertumpang tindih. Gugus $-\mathrm{NH}_{2}$ terlihat pada serapan kembar di daerah 1661,98 dan $1640,45 \mathrm{~cm}^{-1}$, dan spektra pada 1077,90 $\mathrm{cm}^{-1}$ yang menunjukkan serapan gugus $\mathrm{C}-\mathrm{O}$. Taut silang antara asam suksinat dengan kitosan membuat gugus $-\mathrm{NH}_{2}$ primer berubah menjadi sekunder atau tersier dengan munculnya spektra baru dari gugus $-\mathrm{C}=\mathrm{O}$ pada daerah $1650 \mathrm{~cm}^{-1}$ dan munculnya gugus N-O pada daerah $1415 \mathrm{~cm}^{-1}$.

Penambahan pati dan PVA dapat ditunjukkan oleh spektra dari CSSAP dan CSSAPP. Secara umum, penambahan kedua senyawa tidak merubah bentuk spektra secara nyata, karena semua gugus modifier adalah sama dengan gugus CSSA. Yang berbeda adalah beberapa pergeseran serapan, karena meruahnya struktur senyawa modifikasi. Gugus $-\mathrm{OH}$ mengalami pergeseran menjadi $3358,10 \mathrm{~cm}^{-1}$, serapan $-\mathrm{C}=\mathrm{O}$ muncul tipis pada daerah $1647,25 \mathrm{~cm}^{-1}$, gugus $\mathrm{N}-\mathrm{O}$ pada daerah $1457,22 \mathrm{~cm}^{-1}$ dan gugus C-O pada daerah $1035 \mathrm{~cm}^{-1}$.

\section{Berat dan Ketebalan}

Data pengukuran berat dan ketebalan bioplastik dapat dilihat pada Tabel 2. Modifikasi menyebabkan berat dan ketebalan bioplastik bertambah. Semakin tinggi total padatan di dalam 
campuran maka ketebalan kemasan akan semakin tinggi. Ketebalan merupakan salah satu parameter yang berpengaruh terhadap penggunaan kemasan, karena semakin tebal bioplastik yang dihasilkan maka semakin baik kemampuan pengemas untuk melindungi produk (Sumarto, 2000). Dalam Japanese Industrial Standard tentang kriteria bioplastik, standar ketebalan bioplastik adalah $\leq 0,25 \mathrm{~mm}$, sehingga dilihat dari ketebalan yang dihasilkan, bioplastik pada penelitian ini memenuhi kriteria standar.

Tabel 2. Data Berat dan Ketebalan Bioplastik

\begin{tabular}{ccc}
\hline Jenis Bioplastik & Berat $(\mathbf{m g})$ & Ketebalan $\left(\mathbf{x ~ 1 0} \mathbf{~}^{-2} \mathbf{m m}\right)$ \\
\hline CS & 54 & 4,7 \\
CSSA & 65 & 6,2 \\
CSSAP & 69 & 7,2 \\
CSSAPP & 71 & 10 \\
\hline
\end{tabular}

\section{Kuat Tarik}

Nilai kuat tarik tersaji pada Gambar 3. Nilai elongasi dan kuat tarik tertinggi didapatkan oleh film kitosan-suksinat/pati/PVA (CSSAPP) dengan nilai elongasi 45\% dan kuat tarik 1,7 MPa. Penambahan PVA (plasticizer) meningkatkan kuat tarik dan kelenturan film. Plasticizer masuk dalam sistem kerangka struktur film, memberi kekuatan mekanik dan kelenturan ketika terjadi peregangan bioplastik bioplastik (Listyaningsih, 2013, Lusiana dkk., 2019). Menurut Apriyanto (2007) PVA memiliki elastisitas dan kekuatan tarik yang tinggi, hal ini menyebabkan persen pemanjangan semakin tinggi atau tingkat elastisitas semakin tinggi.

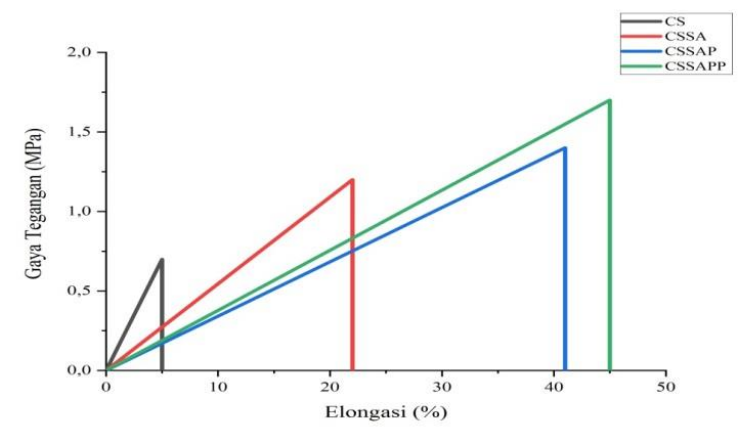

Gambar 3. Grafik Hubungan Kuat Tarik dan Elongasi 
Berdasarkan SNI, kriteria nilai kuat tarik plastik adalah 24,7-302 MPa, berdasar ini bioplastik hasil penelitian belum memenuhi standar SNI. Namun berdasar standar kelenturan SNI yaitu 21-220\%, film bioplastik memenuhi kriteria tersebut.

\section{Porositas}

Pengujian porositas dilakukan untuk memprediksi banyaknya ruang kosong di dalam bioplastik bioplastik. Nilai porositas disajikan pada Tabel 3. Nilai porositas meningkat dengan semakin banyaknya modifikasi pada bioplastik. Film CSSAPP mempunyai nilai porositas tertingi yaitu 38,63\%. Hal ini menunjukkan bahwa dengan adanya penambahan zat aditif PVA meningkatkan ruang kosong di dalam film. Terindikasi bahwa ruang kosong ini lebih seragam, jarak antara satu senyawa dengan senyawa lain lebih teratur sehingga menata bentuk dari fim bioplastik.

\section{Hidrofilisitas}

Berdasar Tabel 3 terlihat bahwa penambahan PVA menurunkan nilai sudut kontak pada bioplastik yang berarti meningkatkan hidrofilisitas film. Keberadaan gugus hidrofil pada PVA meningkatkan hidrofilisitas permukaan bioplastik dan akibatnya menurunkan nilai sudut kontak (Farrokhzad dkk, 2015).

\section{Tabel 3. Nilai Sudut Kontak Bioplastik}

\begin{tabular}{cccc}
\hline Jenis Bioplastik & Porositas (\%) & Sudut Kontak $\left(^{\circ}\right)$ & Swelling (\%) \\
\hline CS & 33 & 44 & 127 \\
CSA & 33 & 43 & 143 \\
CSSA & 34 & 42 & 122 \\
CSSAP & 36 & 40 & 123 \\
CSSAPP & 47 & 35 & 129 \\
\hline
\end{tabular}

\section{Pengembangan (Swelling)}

Pengukuran uji pengembangan pada bioplastik bioplastik bertujuan untuk mengetahui seberapa besar kemampuan bioplastik dalam mengembang karena pengaruh air. Dari Tabel 3 dapat dilihat bahwa CSSAPP mempunyai nilai pengembangan paling tinggi yaitu 129,73\%. 
Penambahan zat aditif PVA yang kaya oleh gugus - OH membuat membran mampu meyerap air lebih banyak daripada bioplastik lain. Hasil ini sejalan dengan nilai porositas, dengan ruang kosong dalam struktur membran yang banyak, kemampuan penyerapan air juga meningkat. Menurut SNI Indonesia 7188.7.2016, nilai pengembangan (swelling) untuk bioplastik yaitu 99\%, sedangkan bioplastik yang dihasilkan mempunyai nilai pengembangan lebih dari 99\%, yang menunjukkan bahwa bioplastik pada penelitian ini melebihi nilai SNI.

\section{Biodegradabilitas Bioplastik}

Uji biodegradabilitas bertujuan untuk mengetahui kecepatan film untuk terurai oleh lingkungan. Biodegradasi dilakukan dengan sisten soil burn, dikubur dalam tanah kompos (Tyasning dan Masykuri, 2012).

Tabel 4. Waktu Biodegradabilitas Bioplastik

\begin{tabular}{cc}
\hline Jenis Bioplastik & Waktu degradasi (hari) \\
\hline CS & 77 \\
CSSA & 62 \\
CSSAP & 15 \\
CSSAPP & 10 \\
\hline
\end{tabular}

Tabel 4 terlihat bahwa bioplastik bioplastik yang paling cepat terdegradasi adalah CSSAPP, yangterdegradasi dalam waktu 10 hari. Hasil tersebut menunjukkan bahwa dengan adanya penambahan PVA maka dapat mempercepat waktu degradasi bioplastik. Selain itu, pati mempunyai sifat biodegradasi dimana pati bersifat hidrofilik sehingga akan mengikat air, air sendiri merupakan media tumbuh bagi bakteri dan mikroba, sehingga kandungan air yang tinggi akan mengakibatkan bioplastik bioplastik menjadi lebih mudah terdegradasi. Menurut Listyaningsih (2013) penambahan pati dan PVA menghasilkan tingkat biodegradasi yang tinggi karena pati dan PVA bersifat hidrofilik sehingga mudah terdegradasi oleh mikroorganisme. Bioplastik CSSA lebih cepat terdegradasi daripada bioplastik kitosan murni, hal itu dikarenakan dengan adanya agen taut silang bersifat lebih hidrofil dibandingkan kitosan murni, sehingga lebih mudah dalam mengikat air dan menyebabkan proses degradasi lebih cepat. Bioplastik kitosan murni membutuhkan waktu paling lama terdegradasi. 
Berdasarkan standar plastik internasional ASTM 5336 menyatakan bahwa lama biodegradasi untuk plastik PLA dari Jepang dan PCL dari Inggris membutuhkan waktu 60 hari untuk dapat terurai. Dari bioplastik yang telah dihasilkan menunjukkan bahwa bioplastik bioplastik yang dihasilkan terdegradasi sebelum 60 hari, sehingga memenuhi standar. Hasil terbaik ditunjukkan CSSAPP yang membutuhkan waktu 10 hari untuk terdegradasi.

\section{KESIMPULAN}

Penelitian ini telah dihasilkan film bioplastik dari paduan CSSA-pati-PVA dengan wujud fisik dari bioplastik berwarna kekuningan dan bening, tidak kaku,tidak mudah patah ketika dilipat-lipat yang menunjukkan bahwa bioplastik tersebut bersifat cukup kuat. Secara umum, penambahan pati dan PVA dapat meningkatkan sifat fisikokimia bioplastik seperti berat dan ketebalan, kuat tarik, porositas, hidrofilisitas, pengembangan (swelling) dan biodegradabilitas. Bioplastik bioplastik CSSAPP memperoleh nilai tertinggi yaitu nilai berat sebesar 0,0712 gram, ketebalan 0,1013 mm, kuat tarik 1,7 MPa, elongasi 45\%, porositas 38,63\%, nilai sudut kontak 34,910, pengembangan 129,73\%. Waktu biodegradasi menurun dari 77 menjadi 10 hari.

\section{UCAPAN TERIMA KASIH}

Terimakasih kepada Fakultas Sains dan Matematika, Universitas Diponegoro atas bantuan Dana berdasar kontrak penelitian No: 2131/UN7.5.8.2/PP/2021

\section{DAFTAR PUSTAKA}

Aditya Nandika, A., Harsojuwono, B. A., dan Arnata, I. W., 2021, Pengaruh Jenis dan Konsentrasi Bahan Pemlastis terhadap Bioplastik Glukomanan. Jurnal Rekayasa dan Manajemen Agroindustri ISSN., 2503: 488X.

Apriyanto, J., 2007, Karakteristik Biofilm dari Bahan Dasar Polivinil Alkohol (PVOH) dan Kitosan, Thesis IPB University.

Farrokhzad, H., Kikhavani, T., Monnaie, F., Ashra, S. N., Koeckelberghs, G., Gerven, T. Van, dan Bruggen, B. Van Der., 2015, Novel composite cation exchange films based on sulfonated PVDF for electrobioplastike separations, Journal of Bioplastike Science., 474:167-174. 
Haghighi, H., Licciardello, F., Fava, P., Siesler, H. W., dan Pulvirenti, A., 2020, Recent advances on chitosan-based films for sustainable food packaging applications, Food Packaging and Shelf Life., 26:100551.

Jabbar, U. F., 2017, Pengaruh Penambahan Kitosan Terhadap Karakteristik Bioplastik dari Pati Kulit Kentang (Solanum Tuberosum, L), Thesis Universitas Islam Negeri Alauddin Makassar.

Listiyaningsih, D., 2013, Pembuatan Dan Karakterisasi Biofilm Pati Gembili-Kitosan Dengan Plasticizer Polivinil Alkohol (PVA), Skripsi Program Studi Kimia, Universitas Negeri Semarang.

Lusiana, R. A., Sangkota, V. D. A., dan Santosa, S. J, 2018, Chitosan succinate/PVA-PEG bioplastike: preparation, characterization and permeation ability test on creatinine. $J$. Kim. Sains Apl., 21(2):80-84.

Lusiana, R. A., Saputry, A. P., dan Prasetya, N. B. A., 2019, Pengaruh Sulfonasi terhadap Karakteristik Fisiko-Kimia Bioplastik Polisulfon, Jurnal Mipa., 42(1):35-42.

Sinaga, Febrianto Rinaldi, Gita, M Hendra dan Rosnadelli., 2014, Pengaruh Penambahan Gliserol Terhadap Sifat Kekuatan Tarik Dan Pemanjangan Saat Putus Bioplastik Dari Pati Umbi Talas. Jurnal Teknik Kimia USU. Vol.3 No.2.

Sumarto, 2000, Mempelajari Pengaruh Penambahan Asam Lemak dan Natrium Benzoat terhadap Sifat Fisik, Mekanik dan Aktifitas Antimikroba Film Edible Kitosan, Skripsi Departemen Ilmu dan Teknologi Pangan Fakultas Teknologi Pertanian Institut Pertanian Bogor.

Tyasning, D. M., dan Masykuri, M., 2012, Pengaruh Penambahan Kitosan terhadap Biodegradasi Plastik Berbahan Dasar Polipropilen, Paper presented at the Prosiding Seminar Biologi. 